\title{
Lower dietary phosphorus supply in pigs match both animal welfare aspects and resource efficiency
}

\author{
Michael Oster, Christian Gerlinger, Kaja Heide, Franziska Just, \\ Luisa Borgelt, Petra Wolf, Christian Polley, Brigitte Vollmar, \\ Eduard Muráni, Siriluck Ponsuksili, Klaus Wimmers
}

Published online: 20 November 2017

\begin{abstract}
Dietary phosphorus frequently exceeds agespecific requirements and pig manure often contains high phosphorus load which causes environmental burden at regional scales. Therefore, feeding strategies towards improved phosphorus efficiency and reduced environmental phosphorus load have to be developed. A 5-week feeding trial was conducted: piglets received medium, lower $(-25 \%)$, or higher $(+25 \%)$ amounts of phosphorus and calcium. Dietary responses were reflected by performance parameters, bone characteristics, and molecular data retrieved from serum, intestinal mucosa, and kidney cortex $(p<0.05)$. Transcripts associated with vitamin D hydroxylation (Cyp24A1, Cyp27A1, Cyp27B1) were regulated by diet at local tissue sites. Low-fed animals showed attempts to maintain mineral homoeostasis via intrinsic mechanisms, whereas the high-fed animals adapted at the expense of growth and development. Results suggest that a diet containing low phosphorus and calcium levels might be useful to improve resource efficiency and to reduce phosphorus losses along the agricultural value chain.
\end{abstract}

Keywords Calcium-phosphorus ratio - Gene expression . Growth · Phosphorus efficiency · Pig · Vitamin D

\section{INTRODUCTION}

The sufficient availability of high-quality agricultural products relies on the sustainable usage of resources. Phosphorus $(\mathrm{P})$ is an irreplaceable component of life and,

Electronic supplementary material The online version of this article (https://doi.org/10.1007/s13280-017-0969-8) contains supplementary material, which is available to authorized users. thus, widely used in all agricultural production systems. However, in pig husbandry the dietary $\mathrm{P}$ levels often exceed animal- and age-specific requirements. Pigs are considered to be major excretors of $\mathrm{P}$ from agricultural systems which lead to a severe environmental burden. In order to balance economic and environmental sustainability related to the uneven density of animal production, novel approaches of $\mathrm{P}$ management aim to slow down the rate of emissions through transformative or incremental system-wide processes (Kebreab 2013). This includes knowledge and measures to reduce $\mathrm{P}$ excretion targeting benefits for animal health and environment.

Decreased intake of $\mathrm{P}$ by farm animals results in lowered $\mathrm{P}$ excretion but also lowered $\mathrm{P}$ retention. At high $\mathrm{P}$ supply, $\mathrm{P}$ absorption and excretion will continue to increase, while $\mathrm{P}$ retention will reach a plateau at certain amounts (Rodehutscord et al. 1999). Hence, an optimal $P$ efficiency requires a high $\mathrm{P}$ absorption, a sufficient skeletal storage, and a low P excretion (Fig. 1) (Poulsen 1994). The addressed mechanisms are interlinked with dietary calcium levels (Berndt and Kumar 2009; Taylor and Bushinsky 2009).

Feeding regimens containing variable calcium and $\mathrm{P}$ contents are known to affect related endocrine levels in mammals (Proszkowiec-Weglarz and Angel 2013; Oster et al. 2016), such as vitamin D (calcitriol) and parathyroid hormone (PTH). The serum levels of both hormones are interdependent due to sophisticated feedback mechanisms involving receptors and transporters localised in the small intestine, bone, and kidneys (Berndt and Kumar 2009). Hence, organismal requirements are ensured by affecting re-/absorbing and excreting tissues. Since PTH regulates the activation of calcitriol via $1 \alpha$-hydroxylase (Friedman et al. 1996), a P-deficient diet was associated with increased renal mRNA abundances of the $1 \alpha$-hydroxylase 


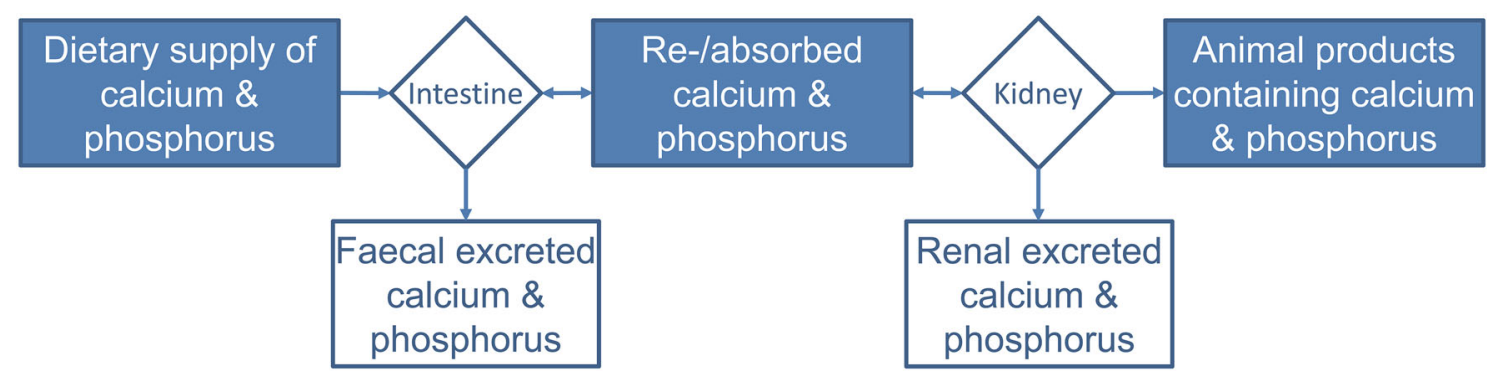

Fig. 1 The flow of calcium and P from diet to animal products and slurry

(Cyp27B1) (Alexander et al. 2008). Consequently, both activity and intracellular redistribution of sodium-dependent phosphate transporters (SLC34 family) rely on dietary $P$ levels in porcine jejunum (Saddoris et al. 2010) and murine kidney cells (Lanaspa et al. 2013). Moreover, the mineralisation of the skeleton relies on dietary $\mathrm{P}$ supplies as indicated by trabecular bone characteristics such as bone mineral density and structure model index (Oster et al. 2016). Interestingly, recent studies suggested that both deficient and excessive $\mathrm{P}$ supplies may have negative effects on bone mineralisation and health (Sørensen 2012).

The characterisation of physiological and molecular processes enabling increased $\mathrm{P}$ efficiency in monogastric species is crucial towards a P-resilient livestock production. The study investigates the effects of wheat/barleybased diets varying in calcium and $\mathrm{P}$ contents on growing pigs. Six tissues and body compartments including serum, bone, duodenum, jejunum, colon, and kidney cortex were used to detect mechanisms of adaptation. We monitored a number of traits, including (i) performance and growth data, (ii) calcium and $\mathrm{P}$ mineral homoeostasis, (iii) bone characteristics, and (iv) expression of candidate genes which represent the receptors of relevant hormones, their in-/activating enzymes and $\mathrm{P}$ transporters.

\section{MATERIALS AND METHODS}

\section{Animals and diets}

The study was approved by the Scientific Committee of the FBN, and the experimental setup was generally licensed by the ethics committee of the federal state of MecklenburgWestern Pomerania, Germany (Landesamt für Landwirtschaft, Lebensmittelsicherheit und Fischerei; LALLF M-V/TSD/7221.3-1-053-15). Twenty-one German Landrace piglets obtained from four litters were randomly assigned to one of three wheat/barley/soybean-based diets (Table S1). Offspring were sired by four boars. The study comprised three to four piglets per sex and dietary group. From weaning (day 28) until slaughter (day 64), piglets received a diet containing low (L, calcium: 0.79\%; P:
$0.56 \%$ ), medium (M; calcium: $1.27 \%$; P: $0.84 \%$ ), or high calcium and P levels (H; calcium: $1.69 \%$; P: $1.02 \%)$. The dietary $\mathrm{P}$ content in compound feed (group $\mathrm{M}$ ) corresponded to current recommendations (GfE 2006). Dietary compositions resulted in only slight variation of the calcium:P-ratios (L: $1.41 ; \mathrm{M}: 1.51 ; \mathrm{H}: 1.65)$. The achieved dietary levels of digestible P were $0.31 \%(\mathrm{~L}), 0.49 \%(\mathrm{M})$, and $0.60 \%(\mathrm{H})$. Neither phytase nor other phosphatases were added. Piglets were individually reared in cages on flat decks in environmentally controlled rooms. The animals had ad libitum access to pelleted feed and water. Piglets were weighed weekly. Feed intake was quantified and feed conversion ratio (FCR) was calculated.

\section{Collection and preparation of serum samples}

At day 64, pigs were narcotised by electrical stunning and sacrificed by exsanguination in the experimental slaughterhouse of FBN. Blood samples were collected from trunk blood. Serum was prepared and samples were stored at $-80{ }^{\circ} \mathrm{C}$ until use. Tissue sampling comprised intestinal mucosa and kidney cortex which were immediately collected, frozen in liquid nitrogen, and stored at $-80^{\circ} \mathrm{C}$. Intestinal samples of $\sim 5 \mathrm{~cm}$ in length have been taken from the duodenum $(10 \mathrm{~cm}$ distal from the pyloric junction), jejunum ( $1 \mathrm{~m}$ distal from the pyloric junction), and the anterior part of the colon (Patterson et al. 2008). Intestinal sections have been washed with PBS to ensuring removal of all feed residues.

\section{Serum hormones and mineral measurements}

Serum calcitriol (Immunodiagnostic Systems, Frankfurt am Main, Germany) and PTH (Immundiagnostik, Bensheim, Germany) were determined in duplicate using commercially available enzyme-linked immunosorbent assays (ELISA) according to manufacturer's protocols. Moreover, serum cortisol and serum thyroid hormones triiodothyronine $\left(\mathrm{T}_{3}\right)$ and thyroxin $\left(\mathrm{T}_{4}\right)$ were determined in duplicate using a commercially available magnetic bead-based quantitative immunoassay (MAGPIX system) according to manufacturer's protocols (Merck Millipore, Darmstadt, 
Germany). Mineral serum measurements (inorganic P, calcium) were analysed with commercial assays using Fuji DriChem 4000i (FujiFilm, Minato, Japan).

\section{Chemical analyses of bones}

The individual left femurs were collected at slaughter (day 64) and stored at $-20{ }^{\circ} \mathrm{C}$ until use. The proximal part $(30 \%$ of total length) of the bones was separated and lyophilised. Subsequently the bones were degreased. The bone tissue was comminuted by ball mill after embrittlement in liquid nitrogen. Wet chemical analyses according to common methods of VDLUFA were applied (Naumann et al. 1976). Contents of crude ash as well as calcium and $\mathrm{P}$ were determined.

\section{RNA isolation}

Total RNA was isolated using TRI Reagent per manufacturer's directions (Sigma-Aldrich, Taufkirchen, Germany), then treated with DNase and purified with the columnbased NucleoSpin RNA II-Kit (Macherey-Nagel, Düren, Germany). RNA integrity was determined by visualisation on a $1 \%$ agarose gel containing ethidium bromide and the concentration was measured using the NanoDrop ND-1000 spectrometer (PEQLAB, Erlangen, Germany). Absence of DNA contamination was verified by PCR amplification of the porcine RPL32 gene (forward primer: $5^{\prime}$-AGCCCAAG ATCGTCAAAAAG- $3^{\prime}$; reverse primer: $5^{\prime}$-TGTTGCTCC CATAACCAATG- $3^{\prime}$ ). All RNA samples were stored at $-80^{\circ} \mathrm{C}$. First-strand cDNA was synthesised from $2 \mu \mathrm{g}$ of total RNA using random primers (Promega, Fitchburg, WI, USA) and oligo d(T) $13 \mathrm{VN}$ in the presence of Superscript III reverse transcriptase (Invitrogen, Karlsruhe, Germany). The final cDNA was diluted with Aqua dest to a total volume of $100 \mu \mathrm{l}$.

\section{Quantitative real-time PCR (qRT-PCR)}

On the transcriptional level, receptors of calcitriol, PTH, and thyroid hormones were analysed, i.e. VDR (vitamin D receptor), PTHIR (parathyroid hormone 1 receptor), and THRA (thyroid hormone receptor alpha). Furthermore, genes encoding calcitriol in-/activating enzymes were analysed, i.e. Cyp24Al (vitamin $\mathrm{D}_{3}$ 24-hydroxylase), Cyp27A1 (vitamin $\mathrm{D}_{3}$ 25-hydroxylase), and Cyp27B1 (1 $\alpha$ hydroxylase). Moreover, analyses of $\mathrm{P}$ transporters comprise SLC34A1 (solute carrier family 34, member 1; NaPi2a), SLC34A2 (solute carrier family 34, member 2; $\mathrm{NaPi} 2 \mathrm{~b}$ ), and SLC $34 A 3$ (solute carrier family 34 , member 2; $\mathrm{NaPi} 2 \mathrm{c})$.

Transcript levels of selected target (VDR, Cyp24A1, Cyp27A1, Cyp27B1, PTH1R, THRA, SLC34A1, SLC34A2,
SLC34A3) and reference genes (RPL32) were quantified by qRT-PCR. Individual mRNA samples $(n=21$ per tissue) were analysed in duplicate on a LightCycler 480 system using the LightCycler 480 SYBR Green I Master (Roche, Mannheim, Germany) according to manufacturer's instructions. Briefly, reactions were performed in a final volume of $10 \mu \mathrm{l}$ using $5.0 \mu \mathrm{l}$ of LightCycler 480 SYBR Green I Master (Roche), $0.5 \mu \mathrm{l}(10 \mu \mathrm{M})$ of each primer (Table S2), $2 \mu \mathrm{l}(40 \mathrm{ng}$ ) cDNA, and $2.0 \mu \mathrm{l}$ of Aqua dest. The temperature profiles comprised an initial denaturation step at $95^{\circ} \mathrm{C}$ for $10 \mathrm{~min}$ followed by 40 cycles consisting of denaturation at $95^{\circ} \mathrm{C}$ for $15 \mathrm{~s}$, annealing at $60^{\circ} \mathrm{C}$ for $10 \mathrm{~s}$, and extension/fluorescence acquisition at $72{ }^{\circ} \mathrm{C}$ for $15 \mathrm{~s}$. Amplified products were subjected to melting curve analyses and gel electrophoresis to verify the absence of non-specific products. For all the assays, threshold cycles were converted to copy numbers using a standard curve generated by amplifying serial dilutions of a corresponding PCR standard $\left(10^{7}-10^{1}\right.$ copies). Transcripts with a mean $\leq 5$ copies per $10 \mathrm{ng}$ RNA transcribed were considered as not detectable (nd).

\section{Data analyses}

Data referring to gene expression, physiological traits, hormones, and bone measurements were analysed via variance analyses (PROC MIXED; SAS version 9.4; SAS Institute, Cary, NC, USA), including effects represented by dietary group, sex, and sire $\left(V_{\mathrm{ijk}}=\mu+\operatorname{diet}_{\mathrm{i}}+\operatorname{sex}_{\mathrm{j}}+\right.$ sire $_{\mathrm{k}}+$ error $_{\mathrm{ijk}}$ ). The retrieved LSmeans were compared using Tukey's post hoc test. The level of significance was set at $p<0.05$.

\section{RESULTS}

\section{Piglet performance and feed conversion ratio}

High levels of dietary calcium and digestible $\mathrm{P}$ revealed decreased live weights compared to low- and medium-fed animals (Table 1). Moreover, cumulative daily feed intake and daily body weight gain were decreased in high-fed animals which resulted in an increased feed conversion ratio (FCR).

\section{Diet-specific serum hormone levels and mineral measurements}

As displayed in Table 2, serum calcitriol was increased in $\mathrm{L}$ animals but decreased in $\mathrm{H}$ animals $(\mathrm{L}>\mathrm{M}>\mathrm{H})$. Regarding parathyroid hormone $(\mathrm{PTH})$, dietary effects were observed between $\mathrm{L}$ and $\mathrm{H}$ samples $(\mathrm{L}<\mathrm{H})$. $\mathrm{T}_{3}$ was decreased in $\mathrm{H}$ animals $(\mathrm{L}>\mathrm{H} ; \mathrm{M}>\mathrm{H})$. No significant 
Table 1 Performance traits of pigs fed experimental diets with low, medium, and high calcium and digestible P contents

\begin{tabular}{|c|c|c|c|c|c|c|c|}
\hline \multirow[t]{2}{*}{ Item } & \multirow[t]{2}{*}{ Unit } & \multicolumn{2}{|l|}{ Low } & \multicolumn{2}{|l|}{ Medium } & \multicolumn{2}{|l|}{ High } \\
\hline & & LSmean & SE & LSmean & SE & LSmean & SE \\
\hline Live weight (day 28) & $\mathrm{kg}$ & 8.4 & 0.4 & 8.4 & 0.4 & 8.4 & 0.4 \\
\hline Live weight (day 64) & $\mathrm{kg}$ & $23.2^{\mathrm{b}}$ & 1.2 & $20.8^{\mathrm{b}}$ & 1.2 & $15.7^{\mathrm{a}}$ & 1.2 \\
\hline Daily feed intake (day 28-day 64) & g/day & $691^{\mathrm{b}}$ & 28 & $622^{\mathrm{a}, \mathrm{b}}$ & 28 & $549^{\mathrm{a}}$ & 28 \\
\hline Daily body weight gain (day 28-day 64 ) & g/day & $403^{\mathrm{b}}$ & 29 & $368^{\mathrm{b}}$ & 29 & $198^{\mathrm{a}}$ & 29 \\
\hline FCR (day 28-day 64) & $\mathrm{g} / \mathrm{g}$ & $1.6^{\mathrm{a}}$ & 0.5 & $1.7^{\mathrm{a}}$ & 0.5 & $3.4^{\mathrm{b}}$ & 0.5 \\
\hline
\end{tabular}

$\overline{\mathrm{a}, \mathrm{b}}$ Indicate significant differences between groups $(p<0.05)$

Table 2 Serum measurements of pigs fed experimental diets with low, medium, and high calcium and digestible P contents

\begin{tabular}{|c|c|c|c|c|c|c|c|}
\hline \multirow[t]{2}{*}{ Item } & \multirow[t]{2}{*}{ Unit } & \multicolumn{2}{|l|}{ Low } & \multicolumn{2}{|l|}{ Medium } & \multicolumn{2}{|l|}{ High } \\
\hline & & LSmean & SE & LSmean & SE & LSmean & SE \\
\hline Calcitriol & $\mathrm{pmol} / \mathrm{l}$ & $572.68^{\mathrm{c}}$ & 26.61 & $392.42^{\mathrm{b}}$ & 37.07 & $291.95^{\mathrm{a}}$ & 26.61 \\
\hline Parathyroid hormone & $\mathrm{pg} / \mathrm{ml}$ & $2.26^{\mathrm{a}}$ & 2.46 & $6.19^{\mathrm{a}, \mathrm{b}}$ & 2.71 & $10.51^{\mathrm{b}}$ & 2.30 \\
\hline $\mathrm{T}_{3}$ & $\mathrm{ng} / \mathrm{ml}$ & $0.81^{\mathrm{b}}$ & 0.08 & $0.82^{\mathrm{b}}$ & 0.08 & $0.47^{\mathrm{a}}$ & 0.08 \\
\hline $\mathrm{T}_{4}$ & $\mathrm{ng} / \mathrm{ml}$ & 11.64 & 1.24 & 10.62 & 1.24 & 11.90 & 1.24 \\
\hline Cortisol & $\mathrm{ng} / \mathrm{ml}$ & 114.76 & 11.52 & 122.45 & 11.48 & 123.98 & 11.52 \\
\hline Inorganic phosphorus & $\mathrm{mg} / \mathrm{dl}$ & 10.02 & 0.50 & 10.45 & 0.49 & 10.61 & 0.50 \\
\hline Calcium & $\mathrm{mg} / \mathrm{dl}$ & 9.61 & 0.29 & 9.64 & 0.29 & 9.51 & 0.29 \\
\hline
\end{tabular}

$\overline{\mathrm{a}, \mathrm{b}, \mathrm{c}}$ Indicate significant differences between groups $(p<0.05)$

Table 3 Femur characteristics of pigs fed experimental diets with low, medium, and high calcium and digestible P contents

\begin{tabular}{|c|c|c|c|c|c|c|c|}
\hline \multirow[t]{2}{*}{ Item } & \multirow[t]{2}{*}{ Unit } & \multicolumn{2}{|l|}{ Low } & \multicolumn{2}{|l|}{ Medium } & \multicolumn{2}{|l|}{ High } \\
\hline & & LSmean & SE & LSmean & SE & LSmean & SE \\
\hline Femur length & $\mathrm{cm}$ & 12.7 & 0.6 & 12.8 & 0.7 & 12.2 & 0.5 \\
\hline $\mathrm{DM}_{\text {fat free }}$ & $\mathrm{mg} / \mathrm{g}$ FM & $296^{\mathrm{a}}$ & 19.6 & $345^{\mathrm{b}}$ & 16.7 & $345^{\mathrm{b}}$ & 14.0 \\
\hline Crude ash & $\mathrm{mg} / \mathrm{g} \mathrm{DM}_{\mathrm{fat}}$ free & $417^{\mathrm{a}}$ & 52.7 & $476^{\mathrm{a}, \mathrm{b}}$ & 51.5 & $487^{\mathrm{b}}$ & 53.3 \\
\hline Calcium & $\mathrm{mg} / \mathrm{g} \mathrm{DM}_{\text {fat free }}$ & 171 & 14.8 & 208 & 53.9 & 210 & 36.7 \\
\hline Phosphorus & $\mathrm{mg} / \mathrm{g} \mathrm{DM}_{\mathrm{fat}}$ free & 73.4 & 10.4 & 82.2 & 12.1 & 92.2 & 30.4 \\
\hline Calcium:phosphorus ratio & & 2.4 & 0.4 & 2.6 & 0.9 & 2.5 & 1.0 \\
\hline
\end{tabular}

$\overline{\mathrm{a}, \mathrm{b}}$ Indicate significant differences between groups $(p<0.05)$

dietary effects on serum $\mathrm{T}_{4}$ levels, cortisol, inorganic $\mathrm{P}$, and calcium were observed.

\section{Bone characteristics}

Femur length was unaffected by diet (Table 3). The fat-free dry matter of the femur $\left(\mathrm{DM}_{\mathrm{fat}}\right.$ free $)$ was decreased in $\mathrm{L}$ animals compared to $\mathrm{M}$ and $\mathrm{H}$ animals $(\mathrm{L}<\mathrm{M} ; \mathrm{L}<\mathrm{H})$. Regarding crude ash, dietary effects were observed between $\mathrm{L}$ and $\mathrm{H}$ samples $(\mathrm{L}<\mathrm{H})$. No significant differences were observed for femoral calcium and $\mathrm{P}$ measures and calculated femoral calcium-P ratio.

\section{Gene expression in re-/absorbing and excreting tissues}

The dietary challenges revealed site-specific transcriptional responses in duodenum, jejunum, colon, and kidney (Table 4). In duodenum, mRNA abundances of Cyp24A1 $(\mathrm{L}>\mathrm{M} ; \mathrm{L}>\mathrm{H})$ and $S L C 34 A 3$ differed significantly between dietary groups $(\mathrm{L}<\mathrm{H})$. In jejunum, genes encoding for Cyp24A1 (L > M; L > H; M $>\mathrm{H}$ ), Cyp27B1 $(\mathrm{L}<\mathrm{H})$, THRA $(\mathrm{M}<\mathrm{H})$, and SLC34A3 $(\mathrm{L}>\mathrm{H})$ were dietdependently altered. In colon, THRA $(\mathrm{L}<\mathrm{H})$ and Cyp27B1 were higher expressed in $\mathrm{H}$ animals $(\mathrm{L}<\mathrm{H} ; \mathrm{M}<\mathrm{H})$. Gene 
Table 4 Tissue-specific relative gene expression and copy numbers of selected transcripts in pigs fed experimental diets with low, medium, and high calcium and digestible $\mathrm{P}$ contents. Significant differences are displayed in bold. $F C$ fold change, $n d$ not detectable

\begin{tabular}{|c|c|c|c|c|c|c|c|c|c|c|}
\hline \multirow[t]{2}{*}{ Tissue } & \multirow[t]{2}{*}{ Gene symbol } & \multirow{2}{*}{$\begin{array}{l}\text { Low versus } \\
\text { medium FC }\end{array}$} & \multirow[t]{2}{*}{$p$} & \multirow[t]{2}{*}{ Low versus high FC } & \multirow[t]{2}{*}{$p$} & \multirow{2}{*}{$\begin{array}{l}\text { Medium } \\
\text { versus high } \\
\text { FC }\end{array}$} & \multirow[t]{2}{*}{$p$} & \multicolumn{3}{|c|}{ Copy number ${ }^{\mathrm{a}}$} \\
\hline & & & & & & & & Min & Max & Mean \\
\hline \multirow[t]{9}{*}{ Duodenum } & VDR & +1.47 & 0.148 & -1.17 & 0.579 & -1.73 & 0.065 & 1599 & 4327 & 2709 \\
\hline & Cyp24A1 & -5.69 & 0.049 & -4.09 & 0.044 & +1.39 & 0.858 & 6 & 225 & 45 \\
\hline & CYP27A1 & +1.06 & 0.884 & +1.31 & 0.396 & +1.24 & 0.514 & 2859 & 15202 & 6949 \\
\hline & CYP27B1 & +1.26 & 0.272 & +1.05 & 0.820 & -1.20 & 0.379 & 8 & 31 & 16 \\
\hline & PTH1R & +1.12 & 0.625 & +1.03 & 0.904 & -1.09 & 0.706 & 16 & 92 & 47 \\
\hline & THRA & +1.13 & 0.583 & +1.16 & 0.458 & +1.03 & 0.870 & 317 & 1098 & 598 \\
\hline & SLC34A1 & nd & nd & nd & nd & nd & nd & nd & nd & nd \\
\hline & SLC34A2 & nd & nd & nd & nd & nd & nd & nd & nd & nd \\
\hline & SLC34A3 & -1.13 & 0.662 & -2.47 & 0.032 & -2.18 & 0.095 & 84 & 762 & 268 \\
\hline \multirow[t]{9}{*}{ Jejunum } & VDR & +1.05 & 0.777 & -1.38 & 0.149 & -1.45 & 0.092 & 823 & 4604 & 2206 \\
\hline & Сyp24A1 & -45.37 & $<0.001$ & -528.81 & $<0.001$ & -11.66 & 0.006 & 0 & 412 & 65 \\
\hline & CYP27A1 & -1.52 & 0.239 & -1.43 & 0.299 & +1.07 & 0.876 & 35 & 769 & 313 \\
\hline & CYP27B1 & +1.25 & 0.439 & +1.86 & 0.015 & +1.49 & 0.072 & 3 & 15 & 8 \\
\hline & PTH1R & -1.27 & 0.558 & +1.45 & 0.217 & +1.83 & 0.081 & 2 & 20 & 9 \\
\hline & THRA & -1.18 & 0.245 & +1.23 & 0.092 & +1.45 & 0.009 & 728 & 1843 & 1169 \\
\hline & SLC34A1 & nd & nd & nd & nd & nd & nd & nd & nd & nd \\
\hline & SLC34A2 & nd & nd & nd & nd & nd & nd & nd & nd & nd \\
\hline & SLC34A3 & -1.36 & 0.130 & -1.86 & 0.013 & -1.37 & 0.246 & 485 & 2698 & 1612 \\
\hline \multirow[t]{9}{*}{ Colon } & VDR & +1.08 & 0.673 & -1.17 & 0.449 & -1.26 & 0.248 & 722 & 2874 & 1602 \\
\hline & Сур24A1 & nd & nd & nd & nd & nd & nd & nd & nd & nd \\
\hline & CYP27A1 & -1.23 & 0.348 & -1.32 & 0.213 & -1.08 & 0.750 & 110 & 543 & 262 \\
\hline & CYP27B1 & +1.94 & 0.077 & +3.33 & $<0.001$ & +1.72 & 0.014 & 12 & 74 & 34 \\
\hline & PTH1R & +1.27 & 0.368 & +1.49 & 0.116 & +1.17 & 0.474 & 24 & 124 & 52 \\
\hline & THRA & +1.21 & 0.155 & +1.45 & 0.006 & +1.20 & 0.111 & 533 & 1236 & 910 \\
\hline & SLC34A1 & nd & nd & nd & nd & nd & nd & nd & nd & nd \\
\hline & SLC34A2 & nd & nd & nd & nd & nd & nd & nd & nd & nd \\
\hline & SLC34A3 & +1.29 & 0.242 & +1.36 & 0.145 & +1.06 & 0.761 & 10 & 33 & 18 \\
\hline \multirow[t]{9}{*}{ Kidney } & VDR & +1.93 & 0.001 & +1.99 & $<0.001$ & +1.03 & 0.781 & 547 & 2175 & 1240 \\
\hline & Сур24A1 & +3.82 & 0.072 & +1.74 & 0.613 & -2.19 & 0.175 & 17 & 5723 & 1248 \\
\hline & CYP27A1 & -1.57 & 0.006 & -1.61 & 0.005 & -1.02 & 0.913 & 467 & 2256 & 1194 \\
\hline & CYP27B1 & -2.01 & $<0.001$ & -1.93 & $<0.001$ & +1.05 & 0.803 & 517 & 3097 & 1274 \\
\hline & PTH1R & +1.02 & 0.808 & +1.02 & 0.805 & +1.01 & 0.998 & 5379 & 10662 & 8235 \\
\hline & THRA & +1.07 & 0.444 & +1.28 & 0.010 & +1.19 & 0.048 & 957 & 1881 & 1265 \\
\hline & SLC34A1 & +1.02 & 0.854 & -1.13 & 0.205 & -1.15 & 0.154 & 35633 & 67928 & 53221 \\
\hline & SLC34A2 & -1.45 & 0.161 & -1.05 & 0.814 & +1.38 & 0.234 & 3 & 19 & 9 \\
\hline & SLC34A3 & -1.12 & 0.154 & -1.22 & 0.020 & -1.09 & 0.286 & 696 & 1363 & 1054 \\
\hline
\end{tabular}

a mRNA copies per 10 ng RNA transcribed

expression in kidney cortex revealed lower mRNA abundances of $V D R$ in $\mathrm{L}$ animals $(\mathrm{L}<\mathrm{M} ; \mathrm{L}<\mathrm{H})$. Renal expression of THRA was increased in $\mathrm{H}$ animals $(\mathrm{L}<\mathrm{H}$; $\mathrm{M}<\mathrm{H}$ ), whereas genes encoding Cyp27A1 and Cyp27B1 were higher expressed in $\mathrm{L}$ animals $(\mathrm{L}>\mathrm{M} ; \mathrm{L}>\mathrm{H})$. Moreover, mRNA abundances of SLC34A3 differed between $\mathrm{H}$ and $\mathrm{L}$ animals $(\mathrm{L}>\mathrm{H})$. Genes encoding for SLC34A1 and SLC34A2 were not detectable in duodenum, jejunum, and colon, whereas $S L C 34 A 3$ was expressed in all analysed tissues.

\section{Trait relationships}

PTH showed negative linear correlations with calcitriol and $\mathrm{T}_{3}$, whereas the latter ones were positively correlated (Fig. 2). Cortisol and serum calcium levels showed positive 


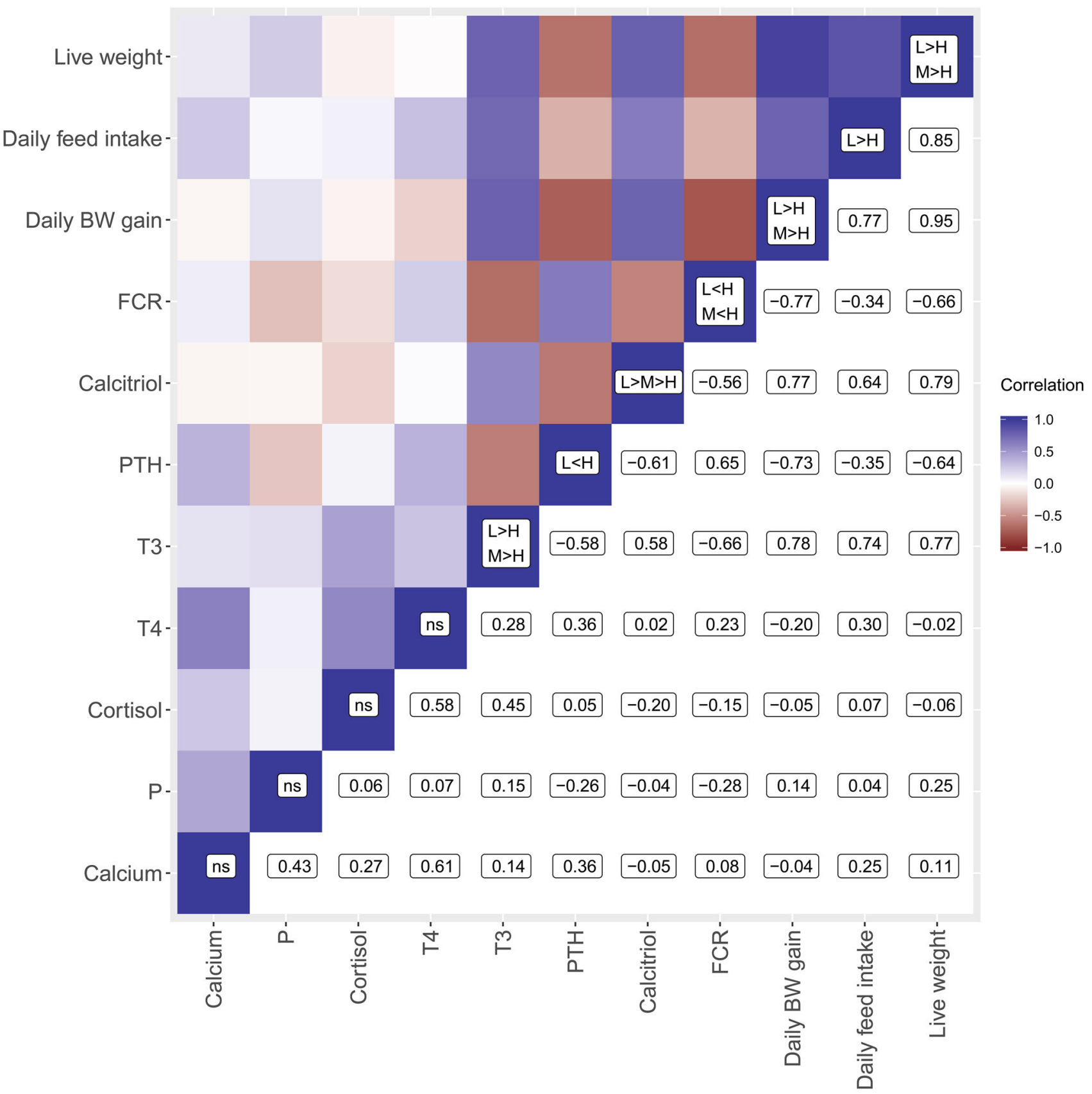

Fig. 2 Heatmap displaying Pearson correlation coefficients comprise performance traits and serum measurements. The diagonals summarise significant alterations indicated in Tables 1 and 2

linear correlations with $\mathrm{T}_{4}$. Serum $\mathrm{P}$ was not correlated to any tested trait. Live weight, daily feed intake, and daily BW gain were positively correlated with calcitriol and $\mathrm{T}_{3}$ but negatively correlated with PTH.

\section{DISCUSSION}

Reaching sustainability will require tracking the fate of $\mathrm{P}$ and to understand how we can decrease $\mathrm{P}$ losses from the agri-environment system and tighten the resource cycle. Indeed, diet and animals are considered the most important determining factors driving $\mathrm{P}$ efficiency. The $\mathrm{P}$ demand should match genetic and physiological requirements to avoid $\mathrm{P}$ excess in manure. In this context, the broad biodiversity of monogastric $\mathrm{P}$ utilisation has been described (Hittmeier et al. 2006; Alexander et al. 2008).

The higher calcium and $\mathrm{P}$ supply in $\mathrm{H}$ animals prompted a lower feed intake, lower body weight gain, and higher FCR. Consequently, the study pointed out molecular routes 
that are responsive to such dietary challenges and, therefore, represented molecules and genes related to $\mathrm{P}$ efficiency. In this study, calcitriol and PTH levels but not serum calcium and P levels were affected by diet. Indeed, endocrine factors such as calcitriol and PTH are known to coordinate serum calcium and P levels (Dusso et al. 2005; Talmage and Mobley 2008). Indeed, calcitriol and PTH were negatively correlated (Fig. 2) to balance enteral absorption, osseous mobilisation, and renal excretion rates as previously reviewed (Berndt and Kumar 2009). Obviously, the endocrine response to diets varying in calcium and $\mathrm{P}$ levels enabled serum mineral homoeostasis. According to previous studies (Engstrom et al. 1985; Sommerville et al. 1985; Riond et al. 2001; Oster et al. 2016), lowered PTH levels but increased calcitriol levels reflect the organismal effort to minimise urinary calcium and $\mathrm{P}$ losses and to enhance enteral calcium and $\mathrm{P}$ absorption in $\mathrm{L}$ samples. In contrast, $\mathrm{H}$ samples aimed to maximise renal calcium and $\mathrm{P}$ losses via lower calcitriol and higher PTH levels.

To regulate mineral homeostasis within the intra- and extracellular fluid, maturation and development provoke dynamic influxes and effluxes of calcium and $P$ which is largely buffered by the osseous storage. Calcitriol and PTH also have an impact on bone tissue via control of dietspecific osteoblast- and osteoclast-mediated actions. It became obvious that calcitriol and PTH responses were sufficient to maintain physiological calcium and $\mathrm{P}$ serum concentrations by recruiting the bone mineral storage. Hence, results suggest an altered bone mineralisation when comparing $\mathrm{L}$ and $\mathrm{H}$ animals which is in agreement with previous studies (Ryan et al. 2011; Varley et al. 2011). Moreover, the skeleton is an important target tissue of thyroid hormones such as $\mathrm{T}_{3}$, which controls bone turnover and maintenance throughout life (Williams 2013; Bassett and Williams 2016). In our study, the reduced $T_{3}$ levels in $\mathrm{H}$ animals compared to $\mathrm{L}$ animals reflect the observed decline in feed intake (Wadden et al. 1990) and may account for impaired bone resorption and formation phases via reduced osteoblast differentiation and function. In fact, reduced $\mathrm{T}_{3}$ levels have been associated with increased bone mineralisation and higher risk of fracture (Vestergaard et al. 2005; Tuchendler and Bolanowski 2014). Interestingly, the decreased endocrine $T_{3}$ levels observed in serum of $\mathrm{H}$ animals were accompanied by increased abundances of THRA encoding the thyroid receptor alpha. Since $T_{3}$ action relies on both hormone availability and mRNA copy number, results might suggest adaptation processes at the receptor level (Kenessey and Ojamaa 2004) to match, e.g. intestinal demands modulating cell proliferation rates (Plateroti et al. 2006).

However, since $T_{3}$ impacts on growth via anabolic and catabolic processes, the reduced $\mathrm{T}_{3}$ levels reflect the lower body weight and BW gain as shown by correlation analyses (Fig. 2). It will be of great scientific interest to find out which molecular mechanisms are able to sense the high calcium and $\mathrm{P}$ content in the diet which lead to a lower feed intake but increased FCR. Indeed, it may be conceivable that differences for feed intake might have affected endocrine responses such as for $\mathrm{T}_{3}$. Interestingly, the low $\mathrm{P}$ supply did not affect growth and feed efficiency; it even tended to improve performance, while mineral homeostasis was maintained. The animals were able to cope with lowered $\mathrm{P}$ supply at least over the period of time tested here.

The endocrine responses to both $\mathrm{L}$ and $\mathrm{H}$ diets indicate the interplay between intestine, bone, and kidney. Whereas mRNA abundances of PTHIR were unaltered in all analysed tissues, the higher abundances of Cyp27Al, and Cyp27B1 in kidney mirrored the increased calcitriol levels on $\mathrm{L}$ diet. These results are in accordance to previous reports when P-restricted diets have been applied to mice (Zhang et al. 2002). Additionally, Cyp27B1 expression was affected in jejunum and colon tissues, although the mRNA copy number was rather low. However, the tissue-specific increased abundances of Cyp27B1 in $\mathrm{H}$ animals might account for a local calcitriol synthesis in the intestine required for, e.g. immunological aspects (Dusso et al. 2005; Liu et al. 2006). In this context, local requirements for calcitriol might be balanced via significantly different Cyp24A1 expression in duodenum and jejunum as the encoded 24-hydroxylase catalyses the first step in the deactivation of calcitriol (Sakaki et al. 2005). Indeed, the dietary challenge in this study revealed a strong transcriptional response of Cyp24Al at local tissue sites. Moreover, $V D R$ was diet-specifically expressed in kidney but not in intestine. The higher renal abundances of VDR might reflect a compensatory regulation of $\mathrm{L}$ animals to achieve a mineral balance. However, VDR is known to initiate various effects in different tissues including intestine and kidney. Specifically, effects were mediated via the VDR-RXR receptor heterodimer binding to vitamin D response elements which are detected in the promoter region of a broad range of genes (Haussler et al. 2013). Despite unaffected VDR in intestine tissues, however, it is conceivable that dietary effects are mediated since calcitriol serum levels were very high in L animals.

Regarding the P transporter represented by the SLC34 family, intestinal $S L C 34 A 1$ and $S L C 34 A 2$ were at the lower detection limit, whereas renal SLC34Al was highly abundant. In contrast, SLC34A2 was highlighted as relevant $\mathrm{P}$ transporter in the posterior parts of the small intestine in mice (Radanovic et al. 2005). In particular, it has been proposed that SLC34A2 is responsible for transcellular $\mathrm{P}$ uptake in jejunum and its mRNA expression is upregulated by decreased $\mathrm{P}$ levels in chickens ( $\mathrm{Li}$ et al. 2012) and rats (Cao et al. 2016). Obviously, this does not reflect the 
porcine responses revealed in this study. In our study, $\mathrm{H}$ animals showed lower abundances of SLC $34 A 3$ in duodenum and jejunum but higher abundances in kidney when compared with $\mathrm{L}$ animals. This pattern might follow superior endocrine responses to minimise the $\mathrm{P}$ influx via intestine and primary urine. Correspondingly, it has been shown that $S L C 34 A 3$ is specifically regulated in response to high $\mathrm{P}$ diets in rats (Segawa et al. 2005). However, it has been proposed that mechanisms involved in $\mathrm{P}$ transport worked independently of transcriptional events (Saddoris et al. 2010).

\section{CONCLUSION}

The responses to the diet containing low calcium and $\mathrm{P}$ levels were sufficient to maintain physiological calcium and $\mathrm{P}$ serum concentrations by recruiting the bone mineral storage. However, the diet containing high calcium and $\mathrm{P}$ levels revealed to be inappropriate for an adequate growth performance since a negative effect of high dietary calcium$P$ levels on feed intake was observed. Indeed, the dynamic influxes and effluxes of calcium and $\mathrm{P}$ among organs and tissues were reflected by the pronounced endocrine and transcriptional responses and might be of critical importance to produce P-resilient phenotypes. The intestinal mucosa and kidney cortex were highlighted as initial sites to maintain mineral homoeostasis. The observed responses contribute to implement feeding strategies to preserve global $\mathrm{P}$ resources and to reduce agricultural residues. Results clearly suggest that the usage of calcium and $\mathrm{P}$ should be monitored and better regulated within a framework of improved governance. Current feeding recommendations for livestock systems need to consider aspects for animal health as well as economic and environmental perspectives to reduce dietary mineral intake in growing pigs.

Acknowledgements The authors thank Hannelore Tychsen, Janine Wetzel, and Angela Garve for their excellent technical help. This work was partly funded by the Leibniz Science Campus Phosphorus Research Rostock and has received funding from the European Union's Seventh Framework Programme for research, technological development, and demonstration as part of the ECO-FCE project (Grant Agreement No. 311794). The Leibniz Institute for Farm Animal Biology (FBN) provided own matched funding. The funders had no role in study design, data collection and analysis, decision to publish, or preparation of the manuscript.

Open Access This article is distributed under the terms of the Creative Commons Attribution 4.0 International License (http:// creativecommons.org/licenses/by/4.0/), which permits unrestricted use, distribution, and reproduction in any medium, provided you give appropriate credit to the original author(s) and the source, provide a link to the Creative Commons license, and indicate if changes were made.

\section{REFERENCES}

Alexander, L., A. Qu, S. Cutler, A. Mahajan, S. Lonergan, M. Rothschild, T. Weber, B. Kerr, et al. 2008. Response to dietary phosphorus deficiency is affected by genetic background in growing pigs. Journal of Animal Science 86: 2585-2595.

Bassett, J., and G. Williams. 2016. Role of thyroid hormones in skeletal development and bone maintenance. Endocrine Reviews 37: 135-187.

Berndt, T., and R. Kumar. 2009. Novel mechanisms in the regulation of phosphorus homeostasis. Physiology 24: 17-25.

Cao, M., R. Fang, J. Chen, and J. He. 2016. Vitamin D3 increased intestinal Na/Pi-IIb and CYP27B1 mRNA level in rats fed lowphosphorus diets. Animal Nutrition Journal 2: 211-217.

Dusso, A.S., A.J. Brown, and E. Slatopolsky. 2005. Vitamin D. American Journal of Physiology 289: F8-F28.

Engstrom, G., R. Horst, T. Reinhardt, and E. Littledike. 1985. Effect of dietary phosphorus levels on porcine renal 25-hydroxyvitamin D-1 alpha- and 24R-hydroxylase activities and plasma 1,25dihydroxyvitamin D3 concentration. Journal of Animal Science 60: 1005-1011.

Friedman, P.A., B.A. Coutermarsh, S.M. Kennedy, and F.A. Gesek. 1996. Parathyroid hormone stimulation of calcium transport is mediated by dual signaling mechanisms involving protein kinase A and protein kinase C. Endocrinology 137: 13-20.

GfE [Ausschuss für Bedarfsnormen der Gesellschaft für Ernährungsphysiologie]. 2006. Empfehlungen zur Energie- und Nährstoffversorgung von Schweinen. DLG-Verlag, Frankfurt am Main. ISBN 978-3769006834 (in German).

Haussler, M., G. Whitfield, I. Kaneko, C. Haussler, D. Hsieh, J. Hsieh, and P. Jurutka. 2013. Molecular mechanisms of vitamin D action. Calcified Tissue International 92: 77-98.

Hittmeier, L., L. Grapes, R. Lensing, M. Rothschild, and C. Stahl. 2006. Genetic background influences metabolic response to dietary phosphorus restriction. Journal of Nutritional Biochemistry 17: 385-395.

Kebreab, E. 2013. Sustainable animal agriculture. ISBN: 9781780640426.

Kenessey, A., and K. Ojamaa. 2004. Ligand-mediated decrease of thyroid hormone receptor- $\alpha 1$ in cardiomyocytes by proteosomedependent degradation and altered mRNA stability. American Journal of Physiology-Heart and Circulatory Physiology 288: H813-H821.

Lanaspa, M., Y. Caldas, S. Breusegem, A. Andrés-Hernando, C. Cicerchi, M. Levi, and V. Sorribas. 2013. Inorganic phosphate modulates the expression of the NaPi-2a transporter in the transgolgi network and the interaction with PIST in the proximal tubule. BioMed Research International. https://doi.org/10.1155/ 2013/513932.

Li, J., J. Yuan, Y. Guo, Q. Sun, and X. Hu. 2012. The influence of dietary calcium and phosphorus imbalance on intestinal NaPi-IIb and calbindin mRNA expression and tibia parameters of broilers. Asian-Australasian Journal of Animal Sciences 25: 552-558.

Liu, P.T., S. Stenger, H. Li, L. Wenzel, B.H. Tan, S.R. Krutzik, M.T. Ochoa, J. Schauber, et al. 2006. Toll-like receptor triggering of a vitamin D-mediated human antimicrobial response. Science 311: 1770-1773.

Naumann, C., C. Barth, R. Bassler, and R. Seibold. 1976. Die chemische Untersuchung von Futtermitteln. Mit 1. Ergänzungslieferung 1983, 2. Ergänzungslieferung 1988, 8. Ergänzungslieferung 2012. Darmstadt, Melsungen, Berlin, Basel, Wien, Radebeul [u.a.]: VDLUFA-Verlag. (in German).

Oster, M., F. Just, K. Buesing, P. Wolf, C. Polley, B. Vollmar, E. Murani, S. Ponsuksili, et al. 2016. Towards improved phosphorus efficiency in monogastrics-Interplay of serum, minerals, 
bone and immune system after divergent dietary phosphorus supply in swine. American Journal of Physiology 310: R917R925.

Patterson, J.K., X.G. Lei, and D.D. Miller. 2008. The pig as an experimental model for elucidating the mechanisms governing dietary influence on mineral absorption. Experimental Biology and Medicine 233: 651-664.

Plateroti, M., E. Kress, J.I. Mori, and J. Samarut. 2006. Thyroid hormone receptor $\alpha 1$ directly controls transcription of the $\beta$ catenin gene in intestinal epithelial cells. Molecular and Cellular Biology 26: 3204-3214.

Poulsen, H.D. 1994. Reduced dietary phosphorus for growing and finishing pigs. Effect on performance, retention and excretion. The National Institute of Animal Science, Report 28, Copenhagen.

Proszkowiec-Weglarz, M., and R. Angel. 2013. Calcium and phosphorus metabolism in broilers: Effect of homeostatic mechanism on calcium and phosphorus digestibility. Journal of Applied Poultry Research 22: 609-627.

Radanovic, T., C. Wagner, H. Murer, and J. Biber. 2005. Regulation of intestinal phosphate transport. I. Segmental expression and adaptation to low-P(i) diet of the type Ilb $\mathrm{Na}(+)-\mathrm{P}(\mathrm{i})$ cotransporter in mouse small intestine. American Journal of Physiology 288: G496-G500.

Riond, J.L., M. Wanner, H. Coste, and G. Parvu. 2001. Pathophysiological effects of low dietary phosphorus in pigs. The Veterinary Journal 161: 165-173.

Rodehutscord, M., M. Faust, and E. Pfeffer. 1999. The course of phosphorus excretion in growing pigs fed continuously increasing phosphorus concentrations after a phosphorus depletion. Archiv für Tierernährung 52: 323-334.

Ryan, W.F., P.B. Lynch, and J.V. O'Doherty. 2011. Compensatory effect of dietary phosphorus on performance of growing pigs and development of bone mineral density assessed using dual energy X-ray absorptiometry. Livestock Science 138: 89-95.

Saddoris, K., J. Fleet, and J. Radcliffe. 2010. Sodium-dependent phosphate uptake in the jejunum is post-transcriptionally regulated in pigs fed a low-phosphorus diet and is independent of dietary calcium concentration. Journal of Nutrition 140: 731-736.

Segawa, H., S. Yamanaka, M. Ito, M. Kuwahata, M. Shono, T. Yamamoto, and K. Miyamoto. 2005. Internalization of renal type IIc Na-Pi cotransporter in response to a high-phosphate diet. American Journal of Physiology 288: F587-F596.

Sakaki, T., N.K. Yamamoto, and K. Inouye. 2005. Metabolism of vitamin D3 by cytochromes P450. Frontiers in Bioscience 10: 119-134.

Sommerville, B., E. Maunder, R. Ross, A. Care, and R. Brown. 1985. Effect of dietary calcium and phosphorus depletion on vitamin D metabolism and calcium binding protein in the growing pig. Hormone and Metabolic Research 17: 78-81.

Sørensen, K.U. 2012. Phosphorus metabolism and bone dynamics in growing-finishing pigs. PhD thesis. Copenhagen: University of Copenhagen.

Talmage, R.V., and H. Mobley. 2008. Calcium homeostasis: Reassessment of the actions of parathyroid hormone. General and Comparative Endocrinology 156: 1-8.

Taylor, J.G., and D.A. Bushinsky. 2009. Calcium and phosphorus homeostasis. Blood Purification 27: 387-394.

Tuchendler, D., and M. Bolanowski. 2014. The influence of thyroid dysfunction on bone metabolism. Thyroid Research 7: 12.

Varley, P.F., J.J. Callan, and J.V. O'Doherty. 2011. Effect of dietary phosphorus and calcium level and phytase addition on performance, bone parameters, apparent nutrient digestibility, mineral and nitrogen utilization of weaner pigs and the subsequent effect on finisher pig bone parameters. Animal Feed Science and Technology 165: 201-209.

Vestergaard, P., L. Rejnmark, and L. Mosekilde. 2005. Influence of hyper- and hypothyroidism, and the effects of treatment with antithyroid drugs and levothyroxine on fracture risk. Calcified Tissue International 77: 139-144.

Wadden, T.A., G. Mason, G.D. Foster, A.J. Stunkard, and A.J. Prange. 1990. Effects of a very low calorie diet on weight, thyroid hormones and mood. International Journal of Obesity 14: 249-258.

Williams, G. 2013. Thyroid hormone actions in cartilage and bone. European Thyroid Journal 2: 3-13.

Zhang, M., X. Wang, J. Wang, N. Compagnone, S. Mellon, J. Olson, H. Tenenhouse, W. Miller, et al. 2002. Dietary phosphorus transcriptionally regulates 25-hydroxyvitamin D-1alpha-hydroxylase gene expression in the proximal renal tubule. Endocrinology 143: 587-595.

\section{AUTHOR BIOGRAPHIES}

Michael Oster is a Post-Doc at the Leibniz Institute for Farm Animal Biology (FBN). His research interests include transcriptional responses following dietary imbalances. He focusses on compensatory growth mechanisms which might occur at the expense of a predisposition for metabolic disturbances.

Address: Institute for Genome Biology, Leibniz Institute for Farm Animal Biology (FBN), Wilhelm-Stahl-Allee 2, 18196 Dummerstorf, Germany.

e-mail: oster@fbn-dummerstorf.de

Christian Gerlinger is a doctoral candidate at the Leibniz Institute for Farm Animal Biology (FBN). His research interests include transcriptional responses following varying dietary phosphorus supply in pigs.

Address: Institute for Genome Biology, Leibniz Institute for Farm Animal Biology (FBN), Wilhelm-Stahl-Allee 2, 18196 Dummerstorf, Germany.

Address: University of Rostock, Justus-von-Liebig-Weg 6b, 18059

Rostock, Germany.

e-mail: gerlinger@fbn-dummerstorf.de

Kaja Heide is a doctoral candidate at the Leibniz Institute for Farm Animal Biology (FBN). Her research interest includes physiological responses following dietary challenges in farm animals.

Address: Institute for Genome Biology, Leibniz Institute for Farm Animal Biology (FBN), Wilhelm-Stahl-Allee 2, 18196 Dummerstorf, Germany.

Address: LUFA-ITL GmbH, Dr.-Hell-Str. 6, 24107 Kiel, Germany. e-mail: heide@fbn-dummerstorf.de

Franziska Just is a doctoral candidate at the Leibniz Institute for Farm Animal Biology (FBN). Within her research she aims to characterise dietary challenges on gene expression with an emphasis on mineral homoeostasis and immune function in pigs.

Address: Institute for Genome Biology, Leibniz Institute for Farm Animal Biology (FBN), Wilhelm-Stahl-Allee 2, 18196 Dummerstorf, Germany.

e-mail: just@ fbn-dummerstorf.de

Luisa Borgelt is a research assistant at the Chair of Nutrition Physiology and Animal Nutrition, University of Rostock. Her research interests include characterising nutritional influences of the intestinal health and well-being in pigs.

Address: Faculty of Agricultural and Environmental Sciences, University of Rostock, Justus-von-Liebig-Weg 6b, 18059 Rostock, Germany. e-mail: luisa.borgelt@uni-rostock.de 
Petra Wolf is a full Professor for Nutrition Physiology and Animal Nutrition at the University of Rostock. Her research interests include phosphorus utilisation in pigs with a special emphasis on approaches tackling the digestibility and absorption of macro-minerals.

Address: Faculty of Agricultural and Environmental Sciences, University of Rostock, Justus-von-Liebig-Weg 6b, 18059 Rostock, Germany.

e-mail: petra.wolf@uni-rostock.de

Christian Polley is a doctoral candidate at the Chair of Fluid Technology and Microfluidics, University of Rostock. His research interests include additive manufacturing, bioprinting and medical imaging technology.

Address: University of Rostock, Justus-von-Liebig-Weg 6b, 18059 Rostock, Germany.

e-mail: christian.polley@uni-rostock.de

Brigitte Vollmar is a full Professor for Experimental Surgery at the University Medical Center Rostock. Her research interests include the mechanistic analysis of organ degeneration and regeneration with special emphasis on visceral organs, the musculoskeletal and cardiovascular system.

Address: Institute for Experimental Surgery, University Medical Center Rostock, Schillingallee 69a, 18057 Rostock, Germany.

e-mail: brigitte.vollmar@uni-rostock.de

Eduard Muráni is a senior scientist at the Leibniz Institute for Farm Animal Biology (FBN). His research interests include the molecular background of traits related to production, adaptation and welfare in farm animals.

Address: Institute for Genome Biology, Leibniz Institute for Farm
Animal Biology (FBN), Wilhelm-Stahl-Allee 2, 18196 Dummerstorf, Germany.

e-mail: murani@fbn-dummerstorf.de

Siriluck Ponsuksili is Head of the research unit Functional Genome Analysis at the Leibniz Institute for Farm Animal Biology (FBN). Her research interests cover the integration of 'omics' data from genome/ epigenome, transcriptome, proteome and metabolome towards improved phosphorus utilisation.

Address: Institute for Genome Biology, Leibniz Institute for Farm Animal Biology (FBN), Wilhelm-Stahl-Allee 2, 18196 Dummerstorf, Germany.

e-mail: ponsuksili@fbn-dummerstorf.de

Klaus Wimmers $(\square)$ is the Director of the Leibniz Institute for Farm Animal Biology (FBN) and full Professor for Animal Breeding and Genetics at the Faculty of Agricultural and Environmental Science, University of Rostock. His research interests include farm animal genomics, with an emphasis on molecular pathways, mechanisms and genes mediating resilience in pigs and poultry.

Address: Institute for Genome Biology, Leibniz Institute for Farm Animal Biology (FBN), Wilhelm-Stahl-Allee 2, 18196 Dummerstorf, Germany.

Address: Faculty of Agricultural and Environmental Sciences, University of Rostock, Justus-von-Liebig-Weg 6b, 18059 Rostock, Germany.

e-mail: wimmers@fbn-dummerstorf.de 